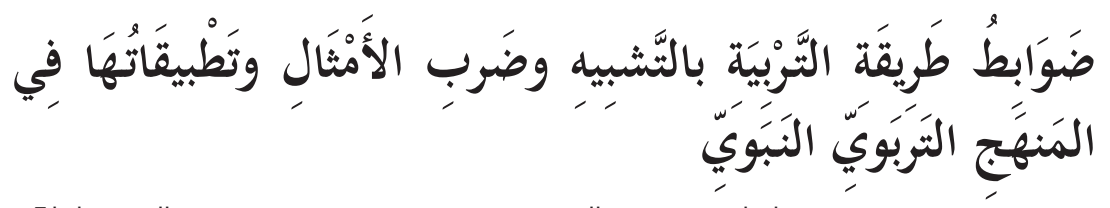

EḠiTIMDE ÖRNEK VERME VE BENZETME YÖNTEMLERININ KURALLARI VE NEBEVÎ EḠiTIM YÖNTEMINDE UYGULANMASI CONDITIONS ANALOGY AND PROVERBS EDUCATIONAL IN THE EDUCATIONAL CURRICULUM OF THE SONNA

\title{
EMAD KANAAN
}

DR. ÖḠR. ÜYESI, KILIS 7 ARALIK ÜNIVERSITESI ILAHIYAT FAKÜLTESI FELSEFE VE DIN

BILIMLERI BÖLÜMÜ

ASSISTANT PROFESSOR, UNIVERSITY OF KILIS 7 ARALIK FACULTY OF THEOLOGY

DEPARTMENT OF PHILOSOPHY AND RELIGIOUS SCIENCES

emadkanaan@kilis.edu.tr

(iD) https://orcid.org/0000-0002-8233-2994

doi http://dx.doi.org/10.29228/k7auifd.30

Makale Bilgisi / Article Information

Makale Türü / Article Types

Araștırma Makalesi / Research Article

Geliș Tarihi / Received

3 Temmuz / July 2019

Kabul Tarihi / Accepted

23 Aralık / December 2019

Yayın Tarihi / Published

Aralık / December 2019

Yayın Sezonu / Pub Date Season

Aralık / December

Atıf / Cite as

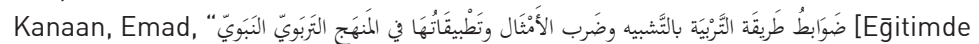
Örnek Verme ve Benzetmé Yöntemlerinín Kurallarí ve Nébévî́ Egitín Yönteminde Uygulanması]". Kilis 7 Aralık Üniversitesi Illahiyat Fakültesi Dergisi - Journal of the Faculty of Theology 6/11 (Aralık/December 2019): 867-890.

Intihal / Plagiarism: Bu makale, en az iki hakem tarafından incelendi ve intihal içermediḡi teyit edildi. / This article has been reviewed by at least two referees and scanned via a plagiarism software.

Copyright $\odot$ Published by Kilis 7 Aralık Üniversitesi, İlahiyat Fakültesi - Kilis 7 Aralık University, Faculty of Theology, Kilis, 79000 Turkey. All rights reserved.

For Permissions

ilahiyatdergisi@kilis.edu.tr 


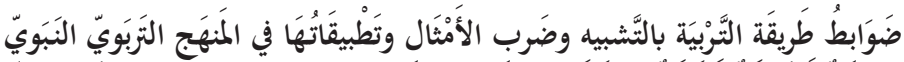

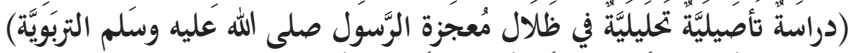

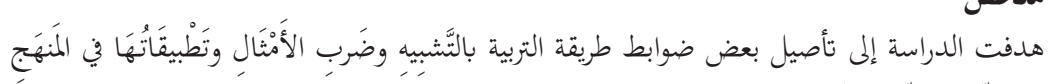

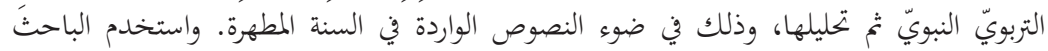

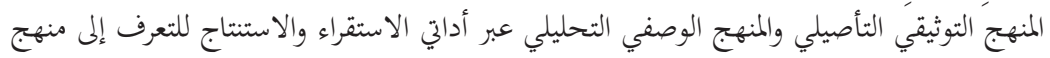

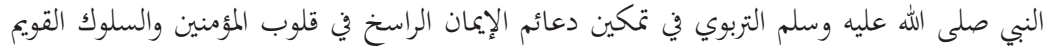

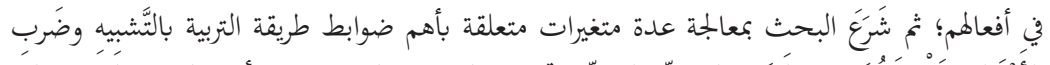

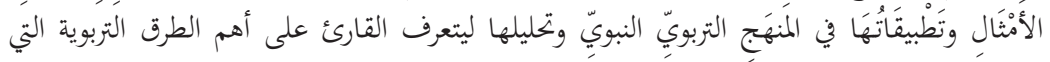

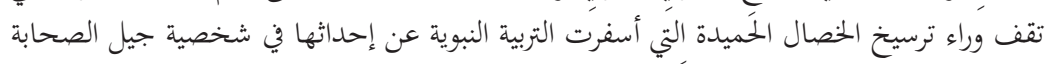

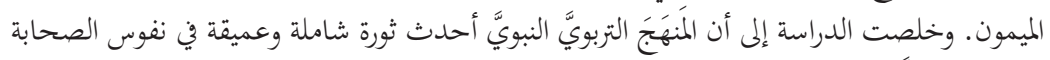

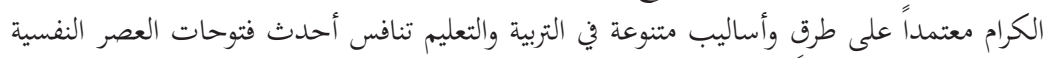

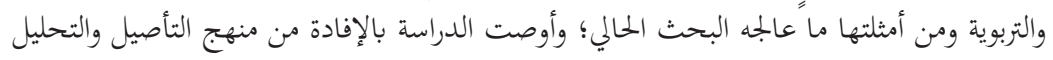

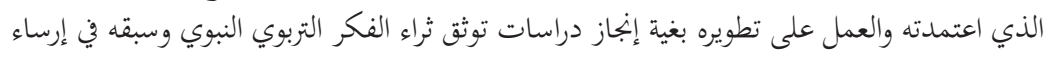
مبادئ البناء الإنساني الإيجابية، وذلك من خلال إلفيل إظهار تعدد أساليب التربية النبوية وتنوع غاياتها.

خلاصة

أشار الأدب التربوي النبوي إلى ضرورة تقدير نوع المبادئ والمعارف التي يراد إيصالها إلى المتعلم في

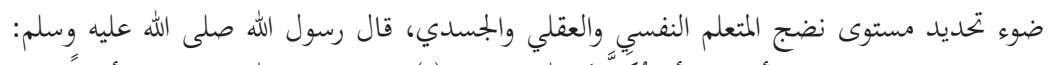

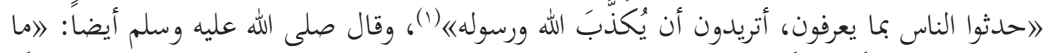

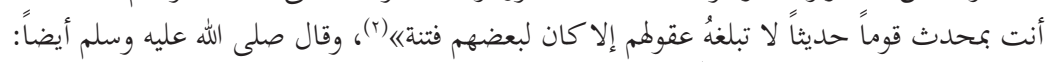

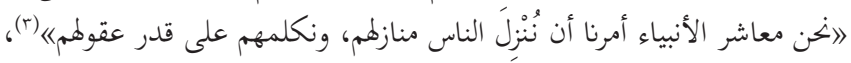

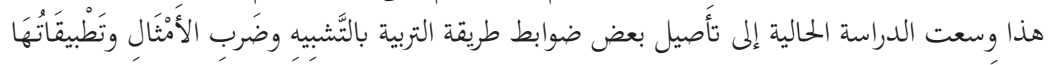

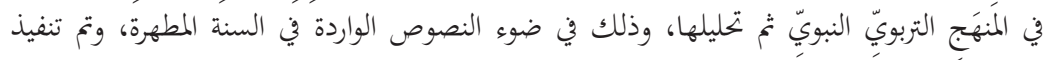

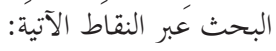

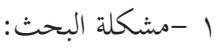

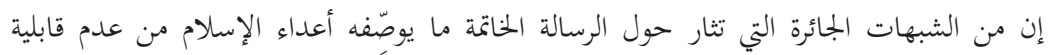

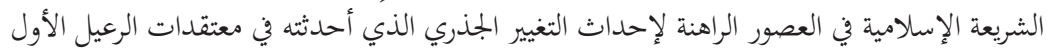

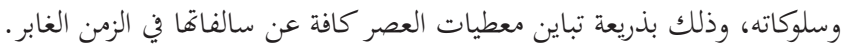

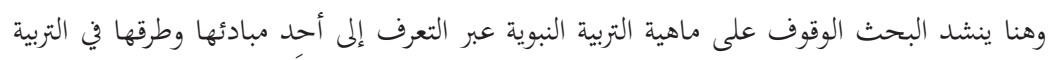

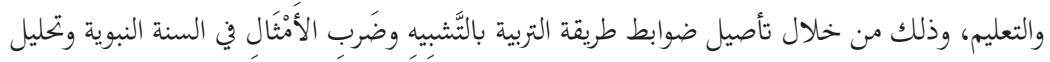




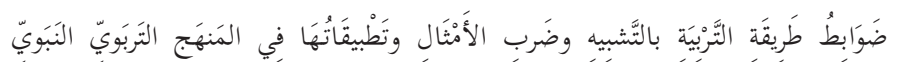

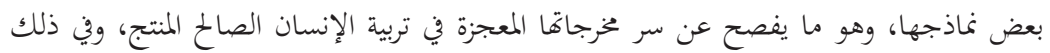

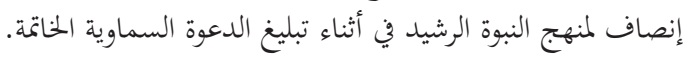

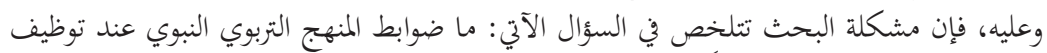

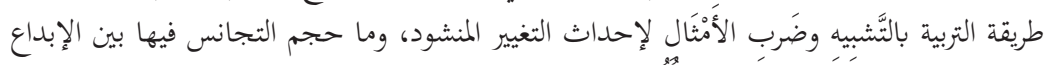

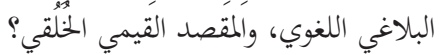

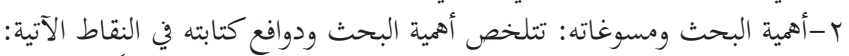

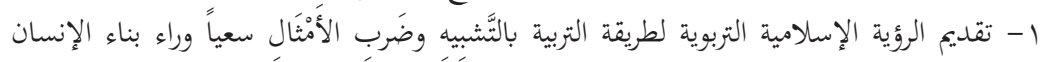
المهتدي الهادي في الدارين.

ץ- التعريف ببعض طرق المنهج التربوي النبوي في أثناء تربية وتعليم جيل الصاحبة.

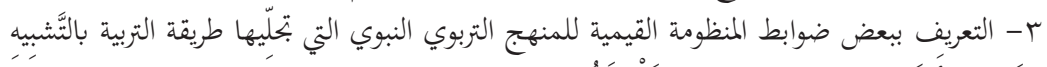

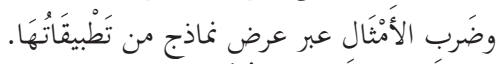

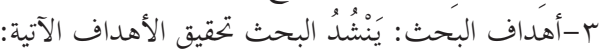

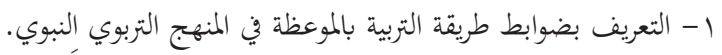

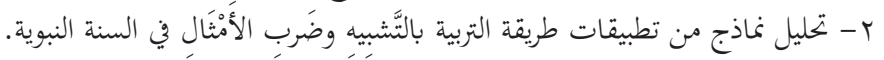

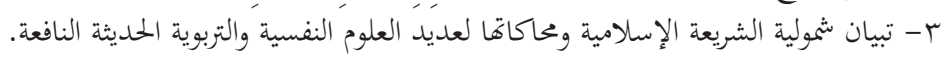
ع -المختوى العلمي: تئيان

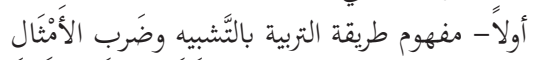

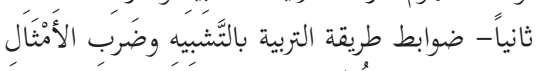

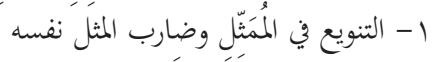

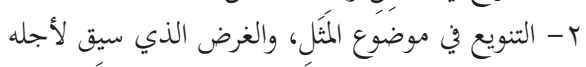

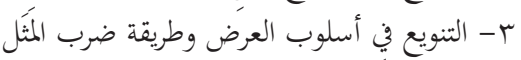
ع - ضرب المثكل في الأحداث والمواقف المتعددة المرضي

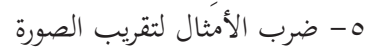
7- استثارة الدافعية بضرب الأمثال

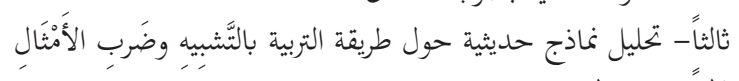

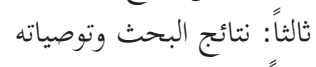
رابعاً: مصادر البحث ومراجعه البحث وتوصياته

واستخدم الباحث المنهج التوثيقي التأصيلي والمنهج الوصفي التحليلي عبر أداتي الاستقراء والاستتناج

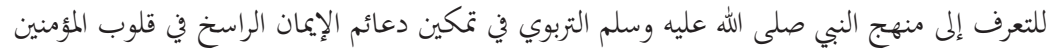

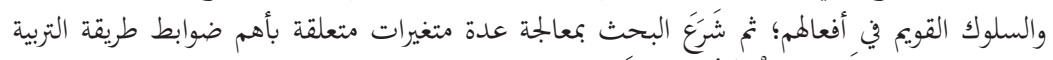

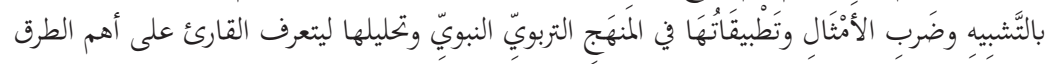

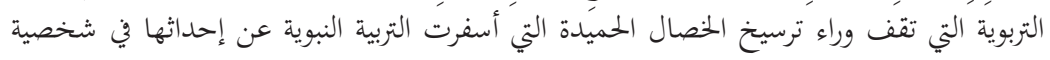
جيل الصحابة الميمون. وخلص البحث إلى جملة من النتائج والتوصيات، ومن أهمها:

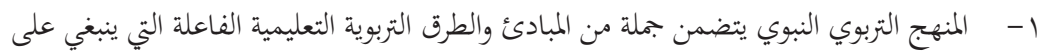
الباحثين المتخصصين في علوم النفس والتربية مدارستها وفق ثوابت الرؤية الإسلامية الرشيدة. 


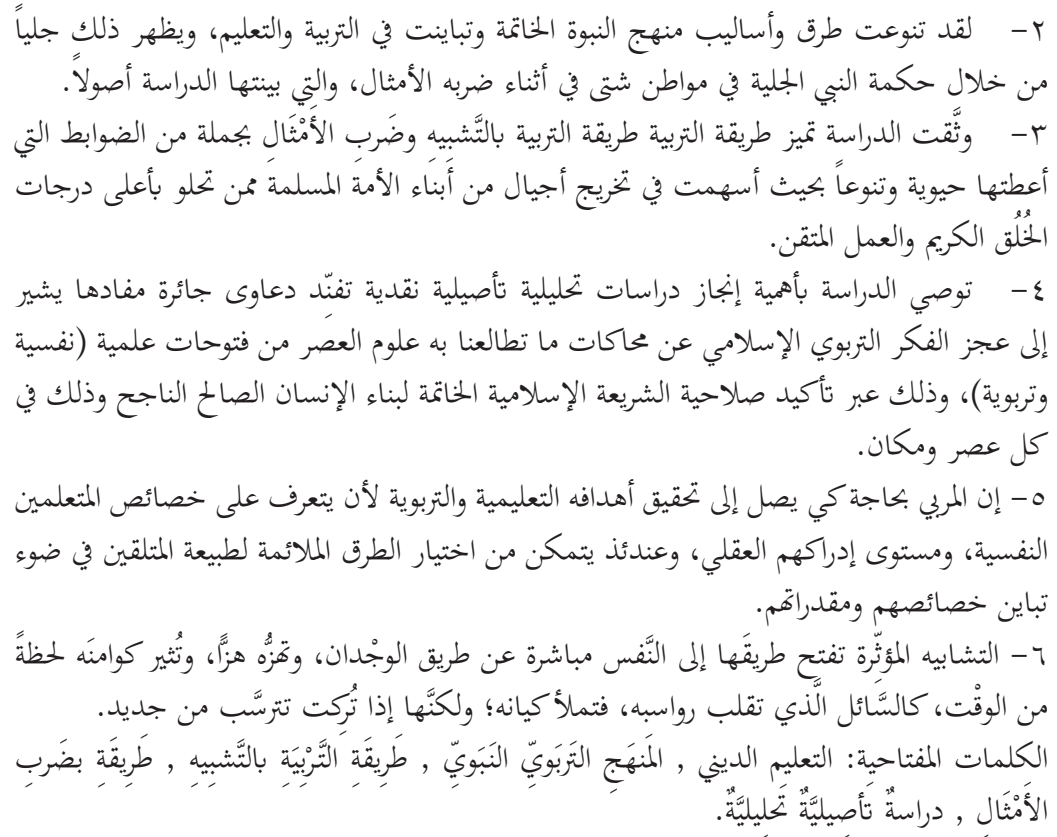

\section{EĞİTIMDE ÖRNEK VERME VE BENZETME YÖNTEMLERININN KURALLARI VE NEBEVÎ EĞITTIM YÖNTEMINDE UYGULANMASI (Eğitimci Peygamber'in (s.a.v) Mucizeleri Gölgesinde Analitik ve Dökümanter Bir Çalışma)}

\section{Öz}

Bu çalışma eğitimde örnek verme ve benzetme yöntemlerinin kurallarını ortaya çıkarmayı ve Nebevî eğitim yönteminde bu kuralların uygulamasını göstermeyi hedeflemektedir. Ayrıca bu konuyu sünnet-i seniyye olarak aktarılan rivayetler ıșığında tahlil etmektedir. Araştırmacı çalışmada tümevarım ve tümdengelim yöntemleriyle, tanımlayıcı analitik ve dökümanter metotlarını kullanmaktadır. Öte yandan araştırmacı Nebî (s.a.v.)'in mü'minlerin kalbine sağlam iman dayanaklarını yerleştirmek ve davranışlarını düzeltmek için kullandığı yöntemi okuyucuya tanıtmak için bu yöntemleri kullanmaktadır. Çalışma eğitimde örnek verme ve benzetme yöntemlerinin en önemli kurallarıyla alakalı birçok değişkeni ve bunların Nebevî eğitim yönteminde uygulanışını ele almaktadır. Ayrıca Nebevî eğitim metodunun sahabe neslinin şahsiyetinde ortaya çıkardığı büyük ve köklü değişimi ele almaktadır. Sonuç olarak, çalışma farklı eğitim ve öğretim yöntemlerine dayanan, Sahabe-i Kirâm üzerinde derinlemesine etkide bulunan Nebevî eğitim yönteminin, günümüz eğitim yöntemleriyle yarışabilecek düzeyde olduğunu belirtmektedir. Bu inceleme bunun örneklerinden biridir. Çalışma bu alanda ileride yapılacak diğer çalışmaların daha başarılı olması için uygulanabilecek bir yöntem önermektedir.

\section{Özet}

Peygamberlik eğitim literatüründe, psikolojik, zihinsel ve fiziksel öğrenicinin olgunluk düzeyini belirleme ışığında öğrenciye aktarılması amaçlanan ilke ve bilgilerin türünü tahmin etmenin gerekliliği belirtildi.Tanrı’nın Elçisi, Tanrı’nın barışı ve nimeti onunla birlikte olsun, “Onunla ve kimseyle konuşun. Tanrı’nın duaları ve 


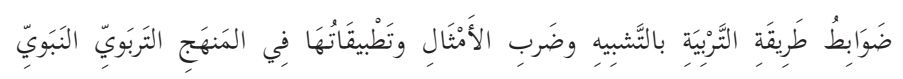

huzuru onun üzerine de olsun: "Sen onların zihinleriyle konuşan modern bir insan değilsin, ama bazıları acı çekiyordu.” Tanrı’nın huzuru ve nimetleri de onun üzerine olsun: "Bizler peygamberlerle birlikteyiz, bize insanlarına evlerini vermelerini emretti ve" onların düşüncelerine göre konuşalım"

$\mathrm{Bu}$ çalışma pedagoji yönteminin bazı kontrollerini, örnekleri ve uygulamalarını kehanet pedagojik yaklaşımında simule ederek, çoğaltarak ve ardından temizlenen yılda yer alan metinler ışığında analiz ederek incelemeyi amaçladı ve araştırma şu noktalarla gerçekleştirildi:

1- Araştırma problemi:

Son mesaj hakkındaki haksız şüphelerden biri, İslam’ın düşmanlarının, günümüzdeki tüm gerçeklerin geçmiş zamanlardaki tüm gerçeklerin geçmişinden farklı olduğu iddiasıyla, ilk nesillerin inanç ve davranışlarında ortaya koydukları radikal değişime yol açamaması olarak tanımladığı şeydir.

Burada araştırma, peygamberlik eğitiminin ilkelerini ve yöntemlerinden birini tanımlayarak, eğitim yönteminin kontrollerini basitlikle kontrol ederek ve peygamberlik yılındaki örnekleriyle çarparak ve iyi ve üretken bir insan yetiştirmenin mucizevi çıktılarının sırrını ortaya koyan modellerini analiz ederek bulmaya çalışır. Son ilahi çağrıyı iletirken rasyonel kehanet yaklaşımının adilliği.

Buna göre, araştırma problemi şu soruda özetlenmiştir: Eğitim yöntemini analojiye uygularken ve istenen değişimi meydana getirmek için örnekler belirlerken kehanet pedagojik yaklaşımının kontrolleri nelerdir ve dilbilimsel yaratıcılık ile etik değer noktası arasındaki homojenliğin boyutu nedir?

2- Araştırmanın önemi ve gerekçeleri: Araştırmanın önemi ve yazmanın sebepleri aşağıdaki noktalarda özetlenmiştir:

A- Rehberli adamı iki ülkeye yerleştirme çabası içinde örnekleri simule edip vurarak İslami eğitim vizyonunun eğitim yöntemine ilişkin vizyonunu sunmak.

B - Sahibah neslinin eğitimi ve öğretimi sırasında peygamberlik pedagojik yaklaşım yöntemlerinden bazılarının tanımı.

C- Peygamberin pedagojik yaklaşımının değer sisteminin bazı denetimlerinin bazılarının tanımlanması, bunların eğitim yöntemiyle sadeliği ve uygulama örneklerini göstererek gösterilmesi.

3-Araştırma Amaçları: Araştırma, aşağıdaki amaçlara ulaşmayı amaçlamaktadır:

A- Eğitim yönteminin denetimlerinin peygamberlik eğitim yönteminde vaaz ile tanitılmasi.

B- Pedagoji yönteminin uygulamalarının örneklerini benzetme ve peygamberlik Sünnet>te atasözleri ile çarpma.

C- Faydalı modern psikolojik ve eğitim bilimleri için İslam hukukunun kapsamlılığını ve simülasyonunu göstermek.

4- Bilimsel içerik:

İlk - benzetim ve örnek olarak eğitim yolu kavramı

İkincisi - pedagoji yönteminin benzetim ve örnek verme ile kontrolleri

1- Aktör çeşitlendirilmesi ve aynı örnek verilmesi

2- İdealler konusuna ve bunun amaçlanma amacına göre çeşitlendirme

3- Sunum tarzının ve ideallerin çeşitlendirilmesi

4- Birden çok olay ve durumda bir örnek oluşturun

5- Yakınlaştırmak için Atasözleri Vur

6- Atasözlerine vurarak motivasyonu motive etmek

III- Eğitim modellerine ilişkin son modellerin benzetim ve örnek verme ile analizi Üçüncüsü: Araştırma bulguları ve önerileri

Dördüncü: Araştırma kaynakları ve referanslar

Araştırmacı, Hz. Peygamber'in eğitim yaklaşımını tanımlamak için tümevarım ve sonuç araçlarını kullanarak açılayıcı belgesel yaklaşımı ve betimsel analitik yaklaşımı, inananların yüreğine sağlam bir şekilde dayanan inanç sütunlarını ve eylem- 
lerinde doğru davranışı sağlamak için barışı ve eylemlerin doğru davranışıyla ilgili çeşitli değişkenleri ele almak için harekete geçme yöntemini kullandı. Peygamberlik eğitim metodu ve analizi, okurun, peygamberlik eğitiminin hayırlı arkadaş neslinin yarattığı kişiliğin yaratmasıyla sonuçlanan iyi huylu niteliklerin sağlamlaştırılmasının arkasında duran en önemli pedagojik metotlarla tanışacaktır.

Araştırma, en önemlileri olan bir takım bulgular ve tavsiyeler ile sonuçlanmıştır:

1- Peygamberlik eğitim yaklaşımı, psikoloji ve eğitim alanında uzmanlaşmış araştırmacıların rasyonel İslami vizyon ilkelerine göre çalışması gereken etkili eğitim ilkeleri ve yöntemleri içerir.

2- Nihai peygamberlik yaklaşımının yöntemleri ve yöntemleri eğitimde çeşitlilik gösterdi ve değişti ve bu, çalışmadaki bulgulara rastlanırken, çeşitli habitatlarda açıkça görülen Peygamberin bilgeliği ile açıkça ortaya çıkıyor.

3- Çalışma, eğitim yöntemini belgelemiştir, eğitim yöntemi, canlılık ve çeşitlilik sağlayan, bir dizi denetim ile simgeleyen ve çarpıcı örneklerle karakterize edilmiştir; böylece, Müslüman milletten çocukların neslinin mezuniyetine en iyi derecede özenli ve gayretli çalışmalara katkıda bulunmuşlardır.

4- Çalışma, İslami eğitim düşüncesinin, her çağda başarılı ve iyi bir insan inşa eden İslami şeriatın geçerliliğini teyit ederek hangi bilimsel bilimlerin (psikolojik ve eğitimsel) bizi tanımadığını gösteren haksız iddiaları çürüten ayrıntılı analitik ve eleştirel çalışmalar yapmanın önemini önermektedir. Bir yer

5- Eğitimcinin, öğrenicilerin psikolojik özelliklerini ve zihinsel farkındalık seviyelerini öğrenmek için eğitim ve öğretim hedeflerine ulaşması gerekir; bu noktada, özelliklerinin ve yeteneklerinin çeşitliliği ışığında, alıcıların doğası için uygun yöntemleri seçebilir.

6- Etkili benzetme, ruha doğrudan vicdan yoluyla yolunu açar, onu sallamakla sallar ve çökeltilerini döndüren sıvı gibi bir an için potansiyelini yükseltir, böylece varlığını doldurur, ancak bırakılırsa tekrar biriktirilir.

Anahtar Kelimeler: Din Eğitimi, Nebevi Eğitim Yöntemi, Benzetme Yöntemiyle ile Eğitim, Örnek Verme Yöntemi ile Eğitim, Analitik ve Dökümanter bir Çalışma.

\title{
CONDITIONS ANALOGY AND PROVERBS EDUCATIONAL IN THE EDUCATIONAL CURRICULUM OF THE SONNA (Consolidation and analytical study in the light of the educational miracle of the prophet)
}

\begin{abstract}
The study aims at Conditions way analogy and proverbs in the educational curriculum of the Prophet and analysis. According to texts coming from al sonna. The investigator (researcher) dose his study through the consolidating documenting method and the des grip live analytic method using inference and induction tools to recognize the prophet curriculum in enforcing (strengthening) the bases of established in the hearts of Muslims. After that the research starts treating many varjbles related to the most important controls of Education method way in the educational curriculum of the Prophet and analysis to the reader to recognize the most important good qualities that caused by prophetic education in flucing the personal. The study can cludes that the educational prophetic curriculum has caused comprehensive and profound revolution in the hearts of noble companions (al sahaba) relying on various methods and techniques in education and learning completing with the latest conquests of psychological and educational era. The study recommends to benefit from the method of consolidation and analysis that it adopts cues and to work to improve it aiming at achieving studies that proves that.
\end{abstract}




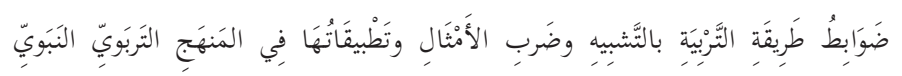

\section{Summary}

The prophetic educational literature pointed to the need to estimate the type of principles and knowledge that are intended to be conveyed to the learner in the light of determining the level of maturity of the psychological, mental and physical learner. The Messenger of God, may God's prayers and peace be upon him, said: "Speak to people with what they know. Do you want to lie to God and His Messenger" (), and he said May God's prayers and peace be upon him also: "You are not a modern people who speak to their minds, but some of them have had an affliction." () And he, peace and blessings of God be upon him, also said: "We are with people of the prophets, instructing us to bring people down their homes, and talk to them according to their minds, () “

The current study sought to establish some of the controls of the pedagogy method by simulating, multiplying examples and their applications in the prophetic pedagogical approach and then analyzing them, in light of the texts contained in the cleansing year, and the research was carried out through the following points:

1 -Research problem:

One of the unfair suspicions raised about the final message is what the enemies of Islam describe in the inability of Islamic law in the present times to bring about the radical change that it brought about in the beliefs and behaviors of the first generation, under the pretext that all the facts of the times differ from their predecessors in the past time.

Here, the research seeks to find out what prophetic education is by identifying one of its principles and methods in education, by establishing the controls of the method of education by similitude and multiplying examples in the prophetic year and analyzing some of its models, which discloses the secret of its miraculous outputs in raising a good and productive man, and in that Fairness of the rational prophecy approach while communicating the final divine call.

Therefore, the research problem is summarized in the following question: What are the controls of the prophetic pedagogical approach when employing the method of education by similitude and giving examples to bring about the desired change, and what is the size of the homogeneity in it between the rhetorical linguistic creativity and the moral value point?

2- The importance of research and its justifications: The importance of the research and the reasons for writing it are summarized in the following points:

A- Presenting the Islamic educational vision of the method of education by simulating and striking out examples in an effort to build the guided man in the two lands.

B - Definition of some of the methods of the prophetic pedagogical approach during the education and teaching of the Sahibah generation.

C- Definition of some of the controls of the value system of the Prophet's pedagogical approach, which is demonstrated by the method of education by similitude and example-giving by showing examples of their applications.

3- Research Objectives: The research seeks to achieve the following objectives:

A- Introducing the controls of the method of education by sermon in the prophetic educational method.

B- Analyzing examples of the applications of the pedagogy method by similitude and multiplying proverbs in the prophetic Sunnah.

C- Demonstrating the comprehensiveness and simulation of Islamic law for many useful modern psychological and educational sciences.

4- Scientific content:

First - the concept of the method of education by similitude and multiplication of proverbs

Secondly - the controls of the pedagogy method by similitude and example-giving 
1- Diversifying the actor and giving the same example

2- Diversification on the subject of ideals, and the purpose for which it was intended

3- Diversification of presentation style and ideals

4- Set an example in multiple events and situations

5- Hit Proverbs to Zoom Image

6- Motivating motivation by striking proverbs

III- Analysis of recent models on the method of education with simile and examplegiving

Third: Research findings and recommendations

Fourth: Research sources and references

The researcher used the authenticative documentary approach and the descriptive analytical approach through the tools of induction and conclusion to identify the educational approach of the Prophet, peace be upon him, in enabling the pillars of faith firmly established in the hearts of believers and the right behavior in their actions. The prophetic educational method and its analysis so that the reader will get acquainted with the most important pedagogical methods that stand behind the consolidation of the benign qualities that the prophetic education resulted in creating in the personality of the auspicious companions generation.

The research concluded a number of findings and recommendations, the most important of which are:

1- The prophetic educational approach includes a set of effective educational principles and methods that researchers specializing in psychology and education should study according to the principles of rational Islamic vision.

2- The methods and methods of the final prophethood approach have varied and varied in education, and this is evident through the wisdom of the Prophet, evident in various habitats, while striking the parables, which were found in the study fundamentally.

3- The study documented the method of education, the method of education is characterized by simulation and multiplication of examples with a set of controls that gave it vitality and diversity so that it contributed to the graduation of generations of the children of the Muslim nation who have the highest levels of decent manners and diligent work.

4- The study recommends the importance of carrying out detailed analytical and critical studies that refute unfair claims, indicating the inability of Islamic educational thought to simulate what scientific science (psychological and educational) studies inspire us with, by affirming the validity of the Islamic Sharia, which is to build a successful and good man in every era A place

5- The educator needs to reach his educational and educational goals in order to learn about the psychological characteristics of learners and their level of mental awareness, at which point he can choose the appropriate methods for the nature of the recipients in the light of the variation in their characteristics and capabilities.

6- Effective analogy opens its way to the soul directly through the conscience, shakes it with a shake, and raises its potential for a moment of time, such as the liquid that turns its sediments, so it fills its being; but if it is left, it is deposited again.

Keywords: Religious Education, Nabawi /Prophetical Education Method, Education in the Method Mimesis, Education in the Method of Exemplification, A Study Analytical and Documentary. 


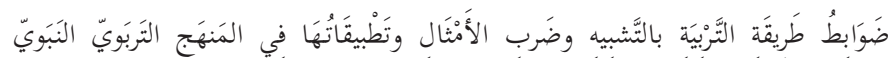

$$
\begin{aligned}
& \text { أولاً: خطة البحث }
\end{aligned}
$$

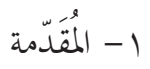

$$
\begin{aligned}
& \text { r- ( ب - مشكلة البحث } \\
& \text { r- أهمية البحث ومسوغاته } \\
& \text { ع - أهداف البحث } \\
& \text { 0- مصطلحات البحث } \\
& \text { 7- الدراسات السابقة } \\
& \text { ثانياً: المحتوى العلمي } \\
& \text { أولاًا-مفهوم طريقة التربية بالتَّشبيه وضَربَ الأَمْثَلَ } \\
& \text { ثانياً- -ضوابط طريقة التربية بالتَّشبيه وضَربِ الأَمثَّالِ } \\
& \text { 1- التنويع في المُمَثّل وضارب المثل نفسه } \\
& \text { ץ- التنويع في موضوع المثكل، والغرض الذي سيق لأجله } \\
& \text { r- التنويع في أسلوب العرض وطريقة ضرب المثَل } \\
& \text { ع- ضرب المثَل في الأحداث والمواقف المتعددة } \\
& \text { ه- ضرب الأمثال لتقريب الصورة } \\
& \text { ج- استثارة الدافعية بضرب الأمثال } \\
& \text { رابعا :مصادر البحث ومراجعه :تئه }
\end{aligned}
$$

أولاً: خطة البحث

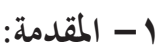

كان رسول الله صلى الله عليه وسلم في تربيته وتوجيهه ينتقي من الأساليب أحسنها وأفضلها، وأكثرها وقعاً في نفس المخاطب، وأقربها الى فهمه ووجدانه، وأوثقها تثبيتاً للعلم في ذهنه، ومن اطلع على كتب السيرة النبوية العطرة، والسنة المشرفة يجد أن النبي صلى الله عليه 
وسلم كان ينوع أساليب تربيته لأصحابه الكرام؛ حيث يكون تارةً سائلاً، وتارةً مجيباً، وفي مَرَّة يضرب المثل، وفي أخرى يستدر طلائع الأفكار، وقد يَصْحَبُ كلامه القَسَمَ في واحدةٍ، وفي ثانية يشرع بتعليم أصحابه مستعيناً بالإشارة والرسم وغيرها من أساليب تربوية متنوعة.

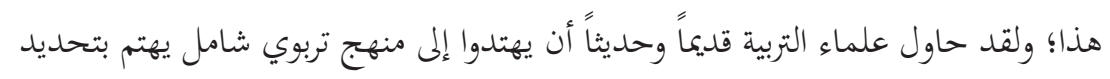
الأساليب والقيم والمعايير الكفيلة بإصلاح الإنسان في مختلف مراحل حياته، وبذلوا في ذلك فلك فئك

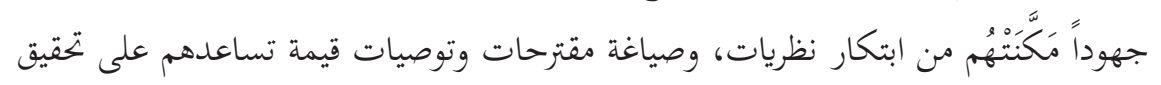
هذا المقصد. وعلى الرغم من ذلك كله فإفم لم يتمكنوا من تحديد المنهج التربوي الدقيق الكفيل بمعالجة

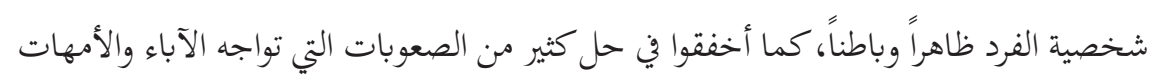
والمربين في هذا المجال. وأمَّا ما يؤسف له حقاً هو أن تنصرف أنظار وبجهودات كثير من المسلمين الفاعلين في حقل

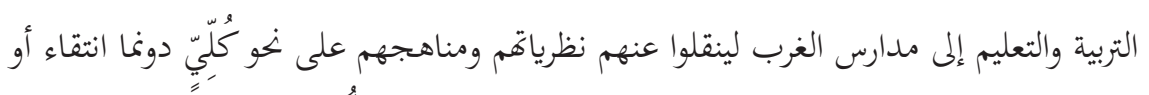

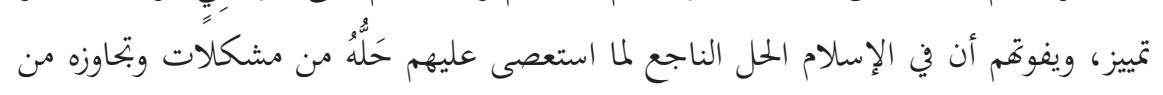

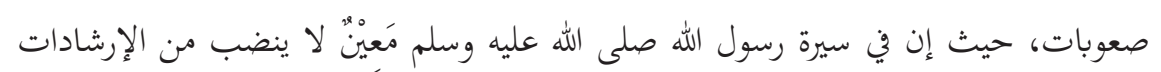

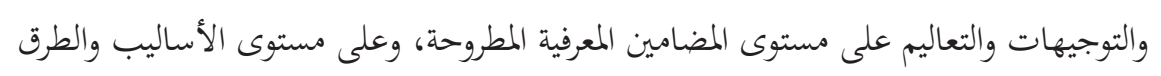
المقترحة.

وهنا رُبَّ قائلٍ يقول: إن التربية الحديثة تعتمد تلكم الأساليب النبوية المتنوعة كافة، وقد

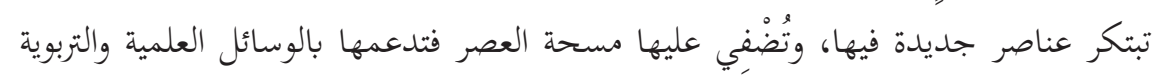
المعاصرة؟!

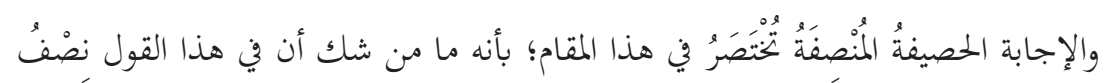

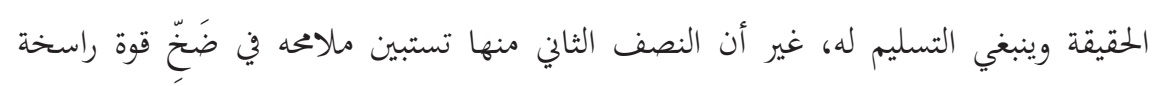

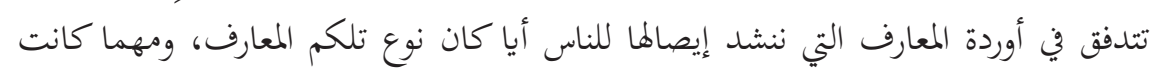

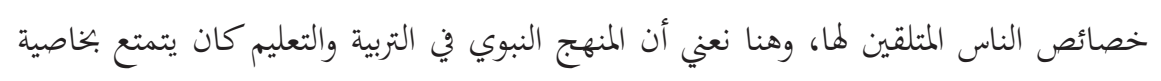
إحياء المعارف التي يدعو إليها من خلال توظيف سياسة العمل بما نعلمه رجاء دعوة الناس إليه

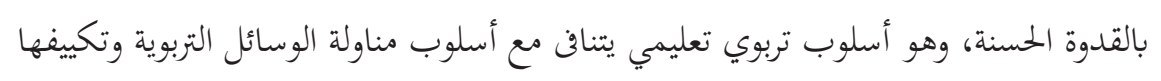




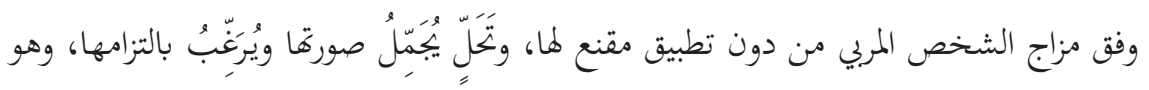

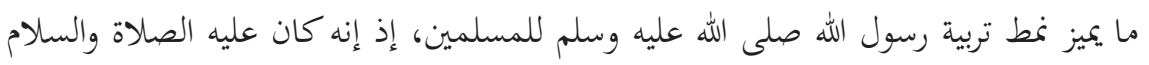
يمثل القدوة والنموذج الذي يترك الوقع في النفوس قبل مخاطبتها، إنها فلسفة إحياء المثّل النبيلة

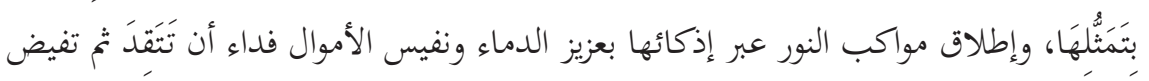
أطياف بركاتحا على الخلق أجمعين. إن المربي بحاجة كي يصل إلى تحقيق أهدافه التعليمية والتربوية لأن يتعرف على خصائص

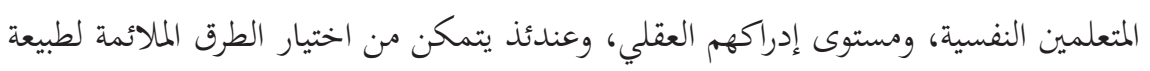
المتلقين في ضوء تباين خصائصهم ومقدراتم. وقد أدرك النبي صلى الله عليه وسلم هذه الحقيقة حيث أشار الأدب التربوي النبوي إلى ضرورة تقدير نوع المبادئ والمعارف التي يراد إيصالها إلى المتعلم في ضوء تحديد هـئ مستوى نضج

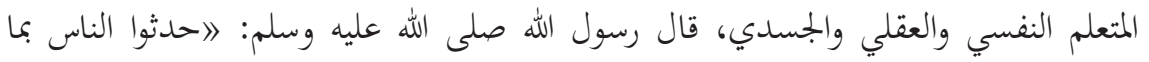

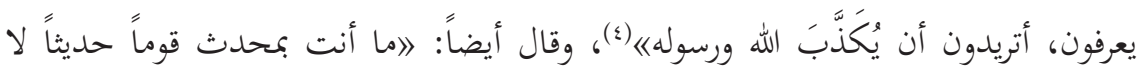

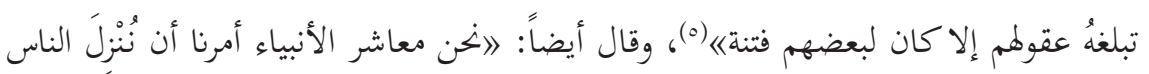

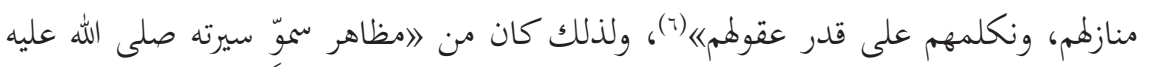
وسلم في تدريس الناس، وفي التعامل معظم، أنه كان يحدثهم وفقاً لمستوياقم العقلية، فكانت أساليب عرضه للأفكار، وإجاباته عن الأسئلة، تختلف في البعد والمستوى من شخص لآنس

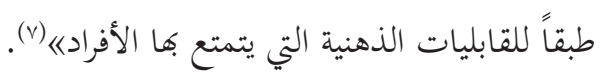
وقد اعتمدت التربية النبوية في طرقها على ثلاثة أسس هي:

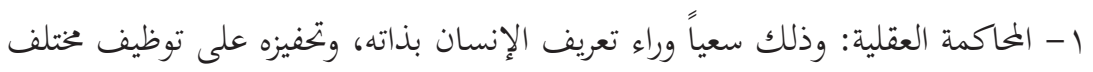

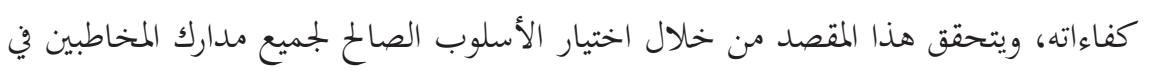
أثناء إدارة دفة جلسات المناقشة والحوار التعليمية. 
ץ- القصص والعبر التاريخية: وقد تمت الإفادة من القصة لما لها من تأثير كبير في نفوس السامعين، ولما يمكن أن تشتمل عليه من مُشٍ كريمة ومعارف متنوعة.

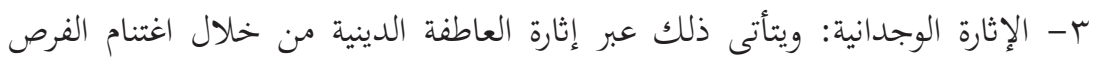
والمناسبات. وفي ضوء تلكم الأسس تتجلى أهم محاور الطرق التربوية في السنة النبوية والتي يمكن اختصار التعريف بها بما يأتي: ا- الطريقة التقريرية: وتعتمد على طرح الحقائق والمعلومات، و تأكيدها بصورة مباشرة على الثى السامع، وقد اعتمدها النبي صلى الله عليه وسلم في المواقف العامة لمخاطبة جموع المسلمين ولمرين

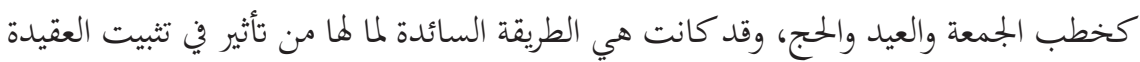

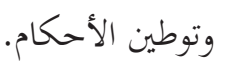

r- الطريقة الاستنتاجية: وتعنى هذه الطريقة بذكر حقائق عامة ينطوي تحتها كثير من

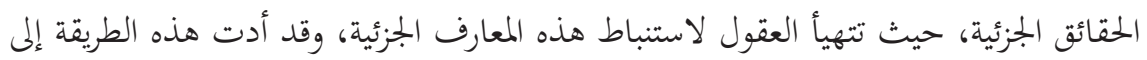
تفعيل الاجتهاد وتمكين علن أصول الفقه. r- الطريقة الاستقرائية: وفيها ينتقل المربي من الجزئيات إلى الكليات ومن الخاص إلى العام،

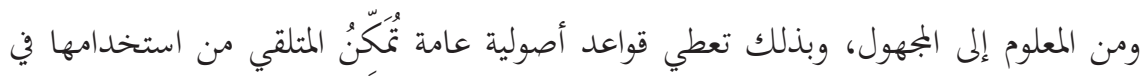

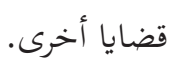
وإن الدراسة الحالية تنشد تسليط الضوء على أهم ملامح وميزات طريقة التربية بالتَّببيه.

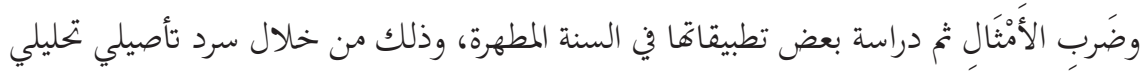
يبين أهم الأساليب النبوية الحكيمة لإنجاز التغير المنشود في الفرد ثم في المجتمع معاً.

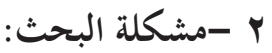

إن من الشبهات الجائرة التي تثار حول الرسالة الخاتمة ما يوصِفه أعداء الإسلام من عدم قابلية الشريعة الإسلامية في العصور الراهنة لإحداث التغيير الجذري الذي أحدثثه في إنداثي معتقدات الرعيل الأول وسلوكاته، وذلك بذريعة تباين معطيات العصر كافة عن سالفاتها في الزمن الغابر. 
وهنا ينشد البحث الوقوف على ماهية التربية النبوية عبر التعرف إلى أحد مبادئها وطرقها في

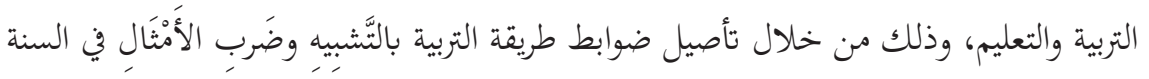

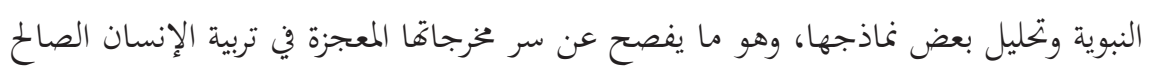
المنتج، وفي ذلك إنصاف لمنهج النبوة الرشيد في أثناء تبليغ الدعوة السماوية الخاتمة.

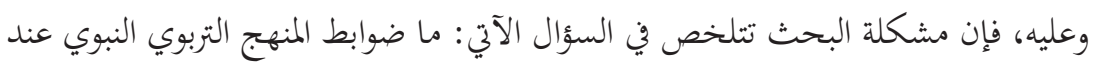

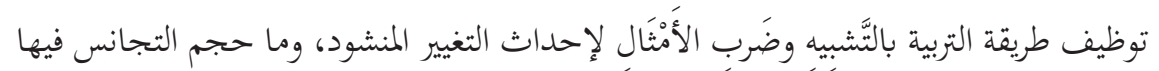

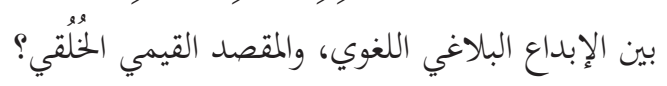

r-أهمية البحث ومسوغاته: تتلخص أهمية البحث ودوافع كتابته في النقاط الآتية:

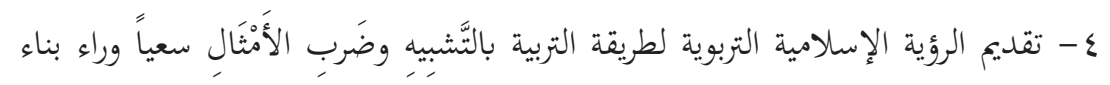
الإنسان المهتدي الهادي في الدارين.

ه- التعريف ببعض طرق المنهج التربوي النبوي في أثناء تربية وتعليم جيل الصاحبة.

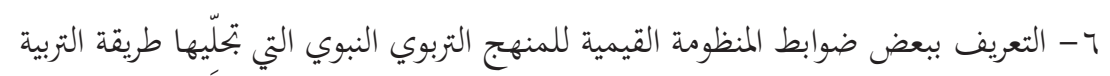

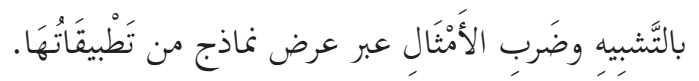

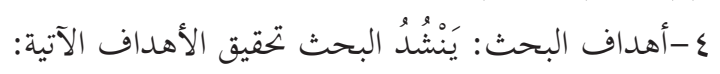
ع - التعريف بضوابط طريقة التربية بالموعظة في المنهج التربوي النبوي.

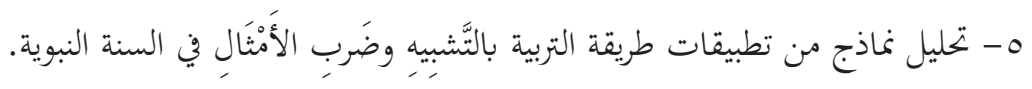

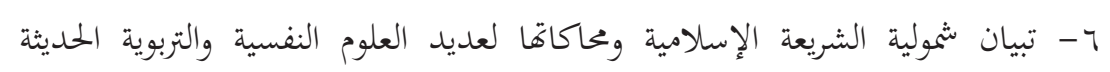

$$
\text { ه- مصطلحات البحث: ومن أهمها الآتي: }
$$

ا - السنَّة النبوية: هي ما صح عن رسول الله صلى الله عليه وسلم من قول أو عمل أو تقرير.

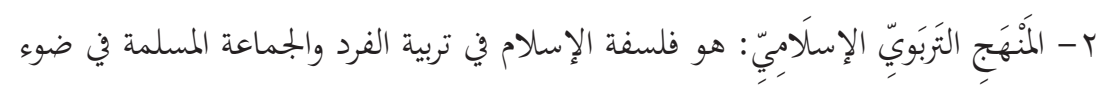
توجيهات الكتاب والسُّنَّة. r- طريقة التربية بالتشبيه وضرب الأمثال: إحدى سبل المنهج التربوي النبوي في التربية والتعليم، وهي تقوم على إيصال جملة المعرف والقيم عبر ضوابط شتى. ج-الدراسات السابقة: من أهم الدراسات السابقة ذات الصلة التي وقع عليها الباحث ما يأتي: 
أ- أساليب تربية الأولاد: الأمثال النبوية في صحيح البخاري (دراسة لغوية دلالية)

$$
\text { • • الباحث: هايخ النشر : عسين . . ب ام }
$$

• ملخص البحث: يتناول هذا البحث تقديم دراسة لغوية في الأمثال النبوية في صحيح

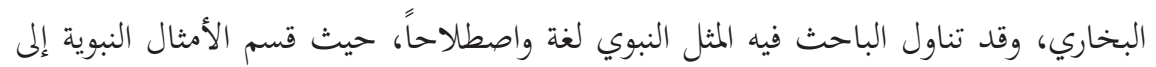

1-الأمثال القياسية، وهي المتضمنة على تشبيه مفرد أو مركب Y-الأمثال السائرة، وهي التي تشيع على ألسنة الناس.

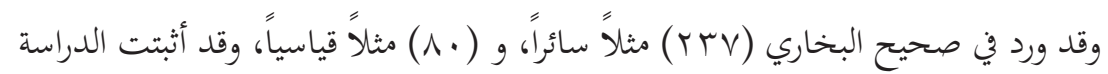
أن النبي صلى الله عليه وسلم كان يتمثل بكام من سبقه، وأن المتخصصين بدراسة الأمثال العربية اهتموا بالأمثال الشعبية وما شاكلها أكثر من اهتمامهم بالأمثال النبوية.

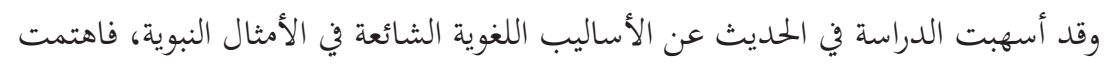
بالتقديم والتأخير والحذف والزيادة والشرط والتوكيد والاستفهام القسم والقصر والاطناب، هذا؛ وفصل الباحث في دلالة تلكم الأساليب اللغوية كافة.

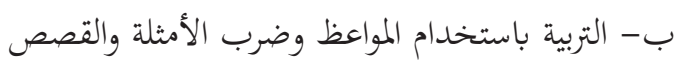

$$
\begin{aligned}
& \text { • الكاتب: محمد جابر } \\
& \text { • تاريخ النشر:9 • . ب بم }
\end{aligned}
$$

• ملخص البحث: تحدث المقال عن أساليب التربية في السئَّة النبوية ومنها أسلوب النصح

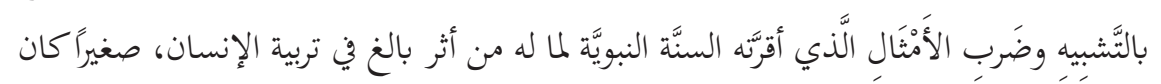

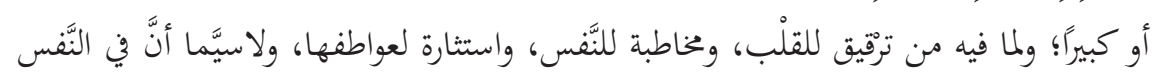

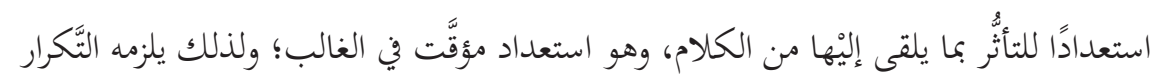

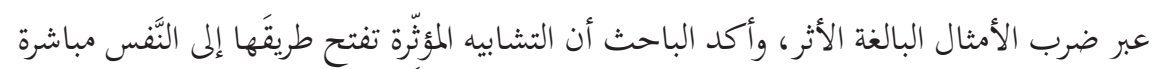

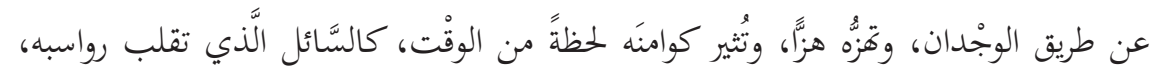

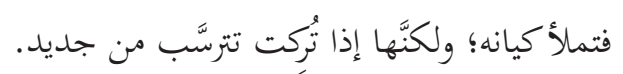

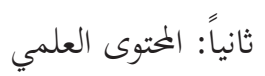




\section{أولاًا-مفهوم طريقة التربية بالتَُّبيه وضَرب الأَمَنًَال:}

فأولى الرسول صلى الله عليه وسلم طريقة التشبيه وضرب الأمثال أهمية كبرى باعتبارها أسلوباً التبال

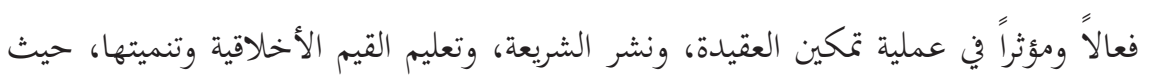
استعان لتوضيح دعوته بطريقة التشبيه وضرب المثل من خلال توظيف ما يشاهده الناس بأم المان

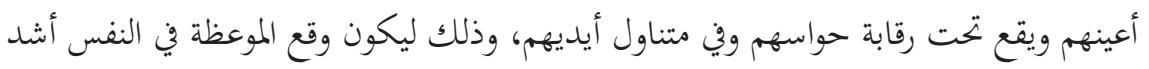

$$
\text { وفي الذهن أرسخ. }
$$

وقد تميزت الأمثال النبوية الشريفة بالقوة البلاغية والتصاوير المنطقية، بالإضافة إلى روعة

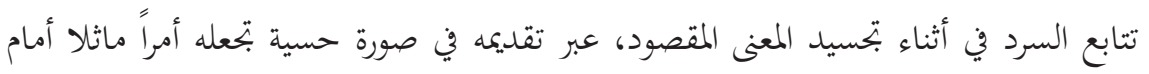
المثلقي.

وإن منهج ضرب الأمثال في البيان النبوي لم يأت لغاية فنية بحتة كغاية الأدباء في تزيين

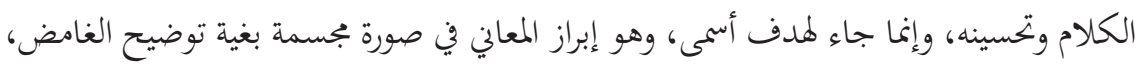

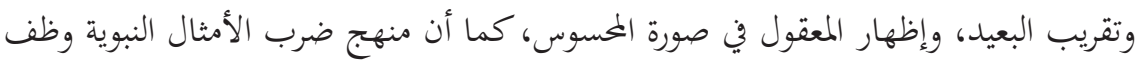

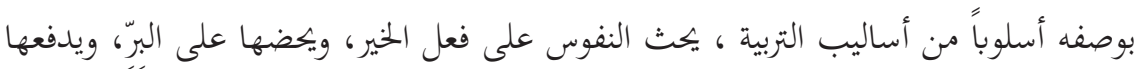

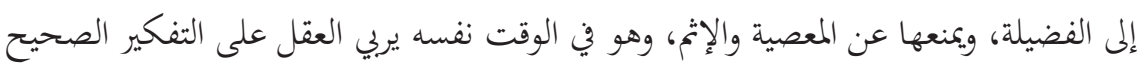
والقياس المنطقي السليم ، ولأجل ذلك كله ضرب النبي صلى الله عليه وسلم طائفة من الأمثال في قضايا مختلفة وفي مواطن متعددة.

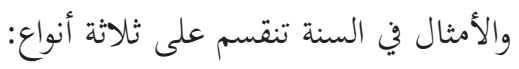

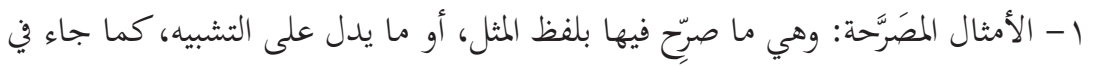

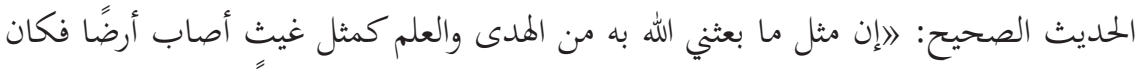

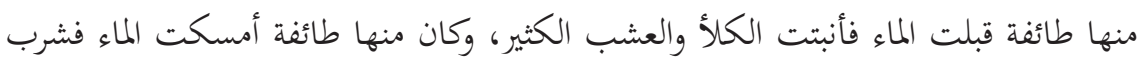
الناس واستقوا وزرعوا، وكانت منها طائفة إنما هي قيعان لا تمسك ماء ولا تنبت كالأ، وذلك

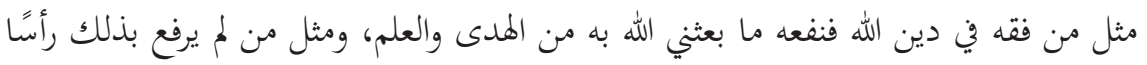
ولم يقبل هدى الله الذى أرسلت بهه". والأمثلة عليها كثيرة.

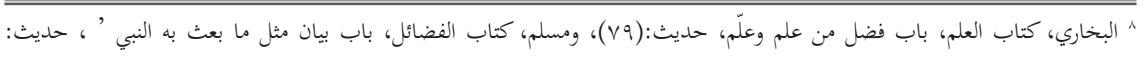


r- والأمثال الكامنة: وهي التي لمُ يُصَسَّْْ فيها بلفظ التمثيل، ولكنها تدل على معانٍ رائعة في إيجازٍ بحيث يكون لها وقعها إذا نقلت إلى ما يشبهها ومثاله: اخير الأمور أوساطها《"، و و

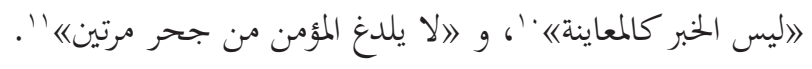
r- والأمثال المرسلة: وهي جمل أرسلت إرسالاً من غير تصريح بلفظ مرتينا التشبيه ومثاله:

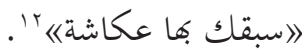

وإن ضرب الأمثال يستفاد منه أمور كثيرة، منها: التذكير، والوعظ، والحث، والزجر، والاعتبار، والتقرير، وتقريب المراد للعقل، وتصويره بصورة المسوس، فإن الأمثال تصور المعاني بصورة الأشخاص؛ لأغها أثبت في الأذهان لاستعانة الذهن فيها بالحواس، ومن ثم كان الغرض من المثل تشبيه الحفي بالجلي والغائب بالشاهد با.

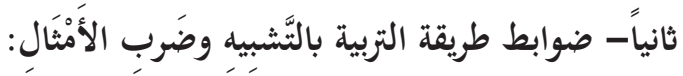

إن المستبصر في الأمثال النبوية يجد التجديد القائم على التنويع صفة ظاهرة فيها، وهو ما لـائه

جعل تلكم الأمثال تعتمد التشبيه المنتمي لماهية الموضوع ركيزة أساسية في بنيتها التربوية: أ_ التنويع في المُمَّلّل وضارب المثل نفسه: ومثال ذلك قول النبي صلى الله عليه وسلم:

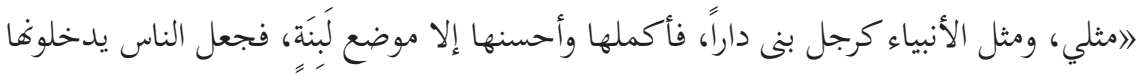

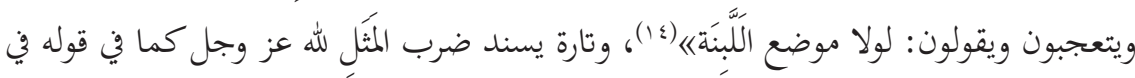

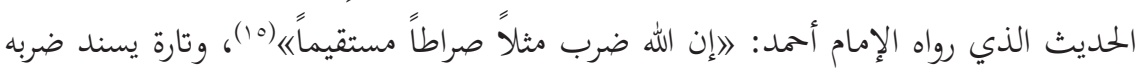

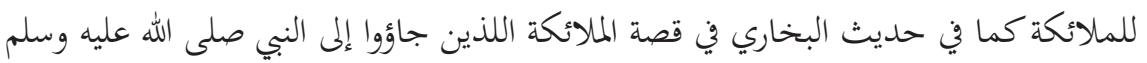

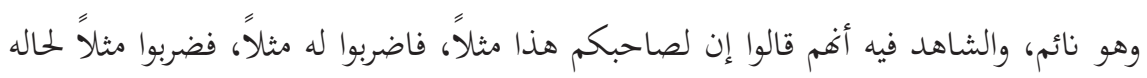

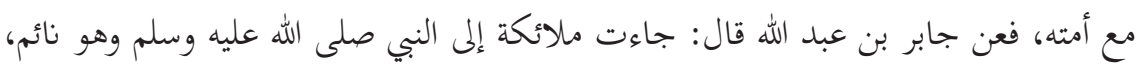

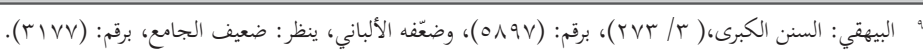

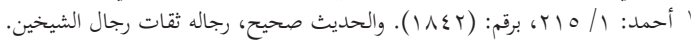

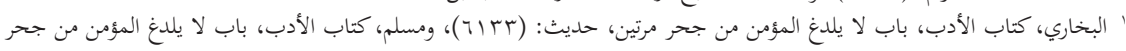

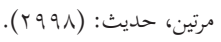

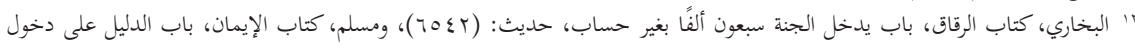

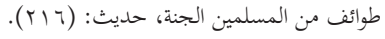

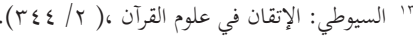

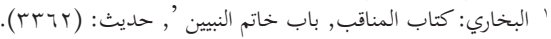

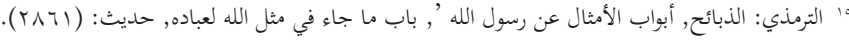


فقال بعضهم: إنه نائم، وقال بعضهم: إن العين نائمة، والقلب يقظان، فقالوا: إن لصاحبكم

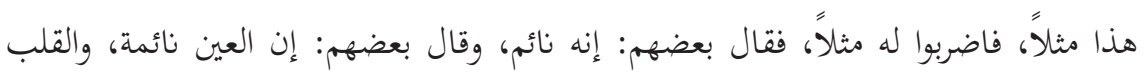

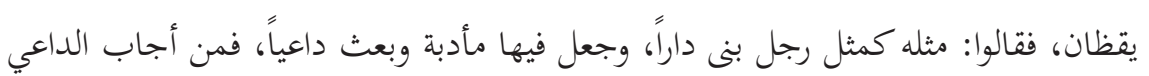

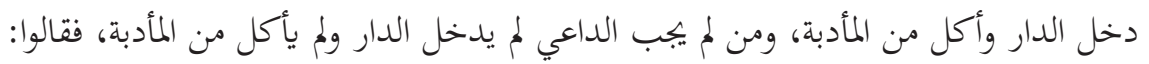

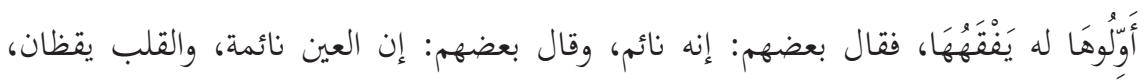

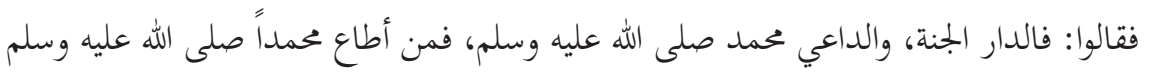
فقد أطاع الله، ومن عصى محمداً صلى الله عليه وسلم فقد عصى الله، ومحمدٌ صلى الله الله عليه

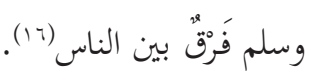

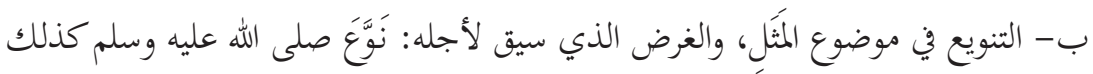

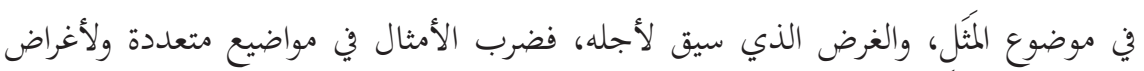

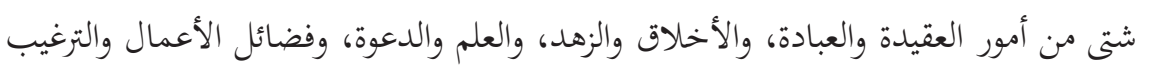

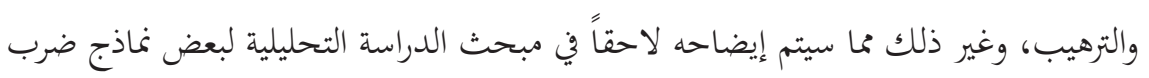

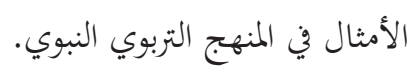

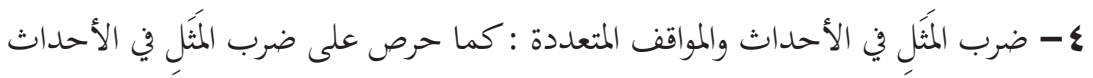
والمواقف المتعددة لتحقيق أهداف تربوية متغايرة، ففي بعض المواقف كان يكفيه أن يرد رداً

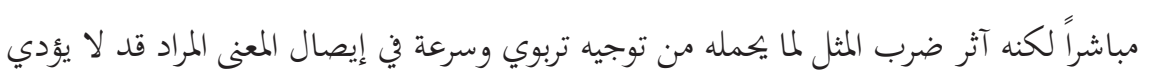

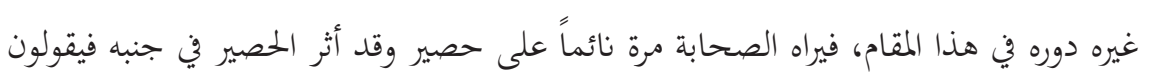

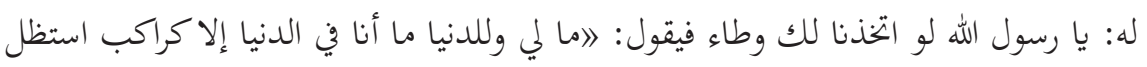

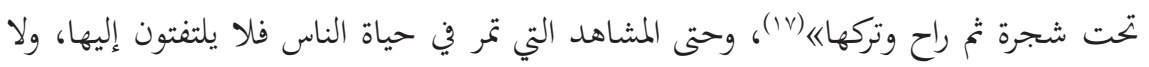

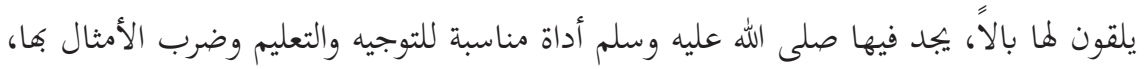

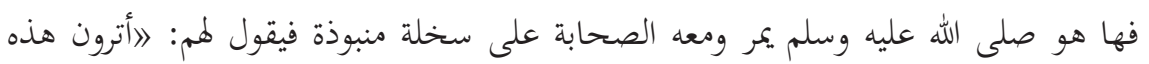
هانت على أهلهاه، فيقولون: يا رسول الله من هوافا ألقوها، فيقول صلى الله عليه وسلم:

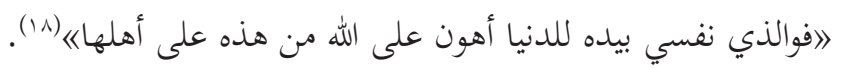


ه- ضرب الأمثال لتقريب الصورة: كان النبي صلى الله عليه وسلم يلجأ إلى ضرب المثل في

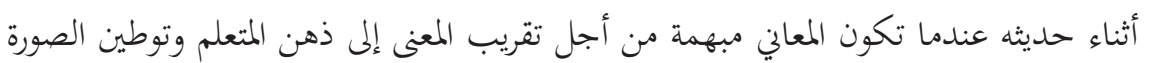
في ذهنه، وهذا الأسلوب كان منهجاً رئيساً في السنة الشريفة.

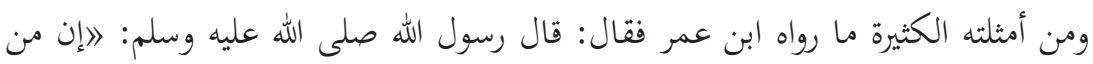
الشجر شجرة لا يسقط ورقها، وإها مثل المسلم فحدثوني ما هي؟؟)، فوقع الناس في شجر

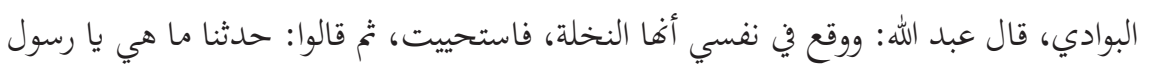
الله؟ قال: اهي النخلة《، قال: فذكرت ذلك لعمر، قال: لأن تكون قلت: هي النخلة، أحب

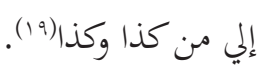

وروى الشيخان بسندها من طريق أبي هريرة قوله صلى الله عليه وسلم: اإنما مثلي ومثل أمتي كمثل رجل استوقد ناراً، فجعلت الدواب والفراش يقعن فيه، فأنا آخذ بحجزكم وأنتم تقحمون فيه (r.).

كما أخبرنا النعمان بن بشير عن النبي صلى الله عليه وسلم أنه قال: ا(مثل القائم على حدود الله والواقع فيها، كمثل قوم استهموا على سفينة، فأصاب بعضهم أعلاها، وبعضهم أسفلها، فكان الذين في أسفلها إذا استقوا من الماء مروا على من فوقهم، فقالوا: لو أنا خرقنا في نصيبنا

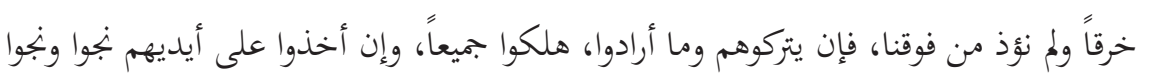

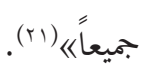

وروى مسلم بسنده من طريق أبي موسى الأشعري عن النبي صلى الله عليه وسلم قال:

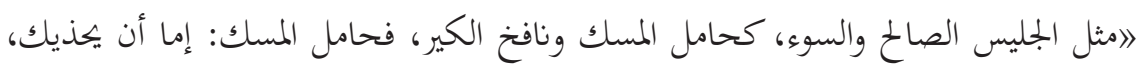

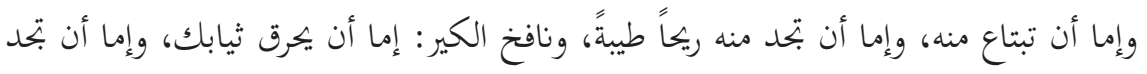

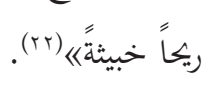

צ- استثارة الدافعية بضرب الأمثال: تسهم الأمثال في استثارة دافعية المتعلم من خلال تقريبها للمعاني المراد إيضاحها للمستمع عن طريق تشبيه المجرد بالمحسوس، وقد اشتمل القرآن 


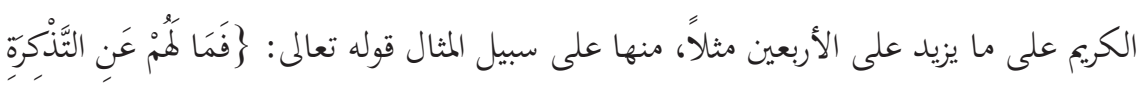

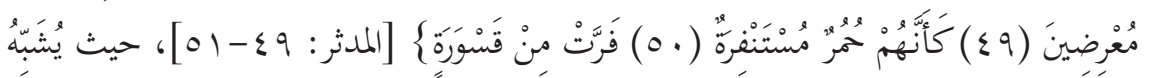

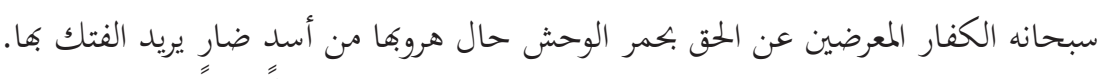

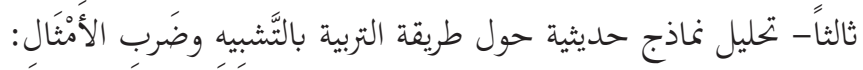

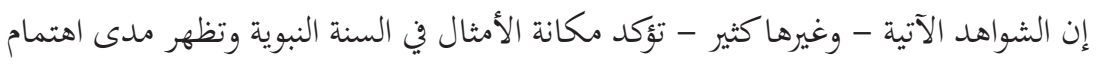

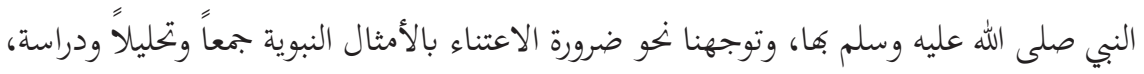
والاستفادة المثلى منها في مناهجنا التعليمية وبرابجنا التربوية والدعوية.

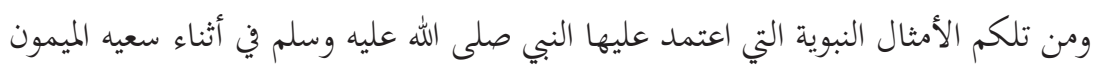

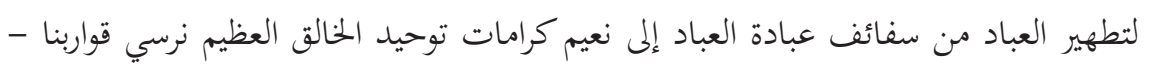
تأصيلاً وتحليلاً - عند هذه القيم النبيلة والأحكام الراشدة الآتية:

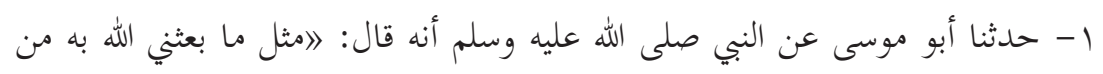

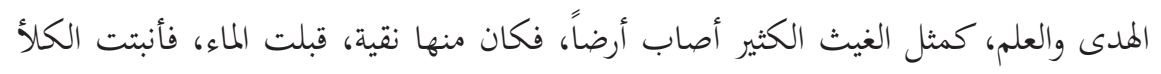

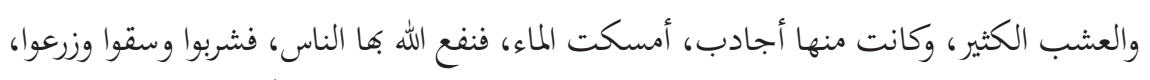

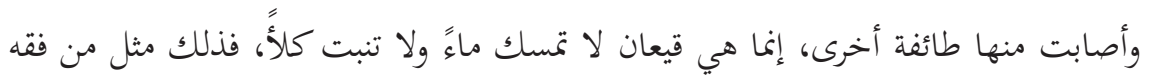

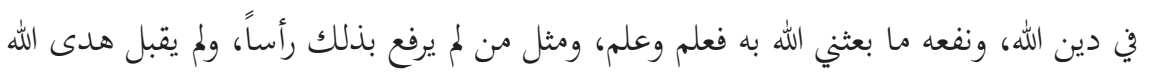

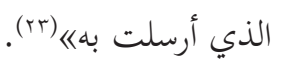

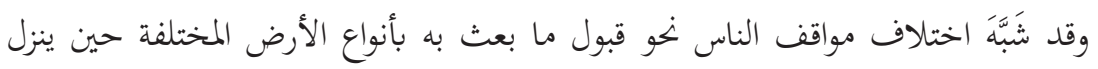

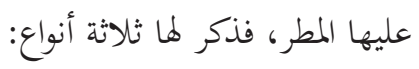

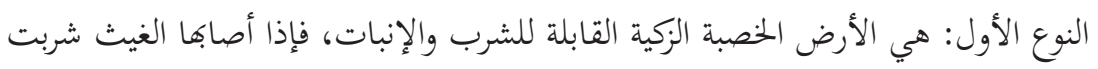

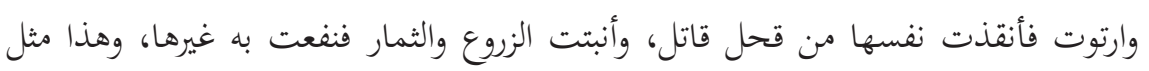

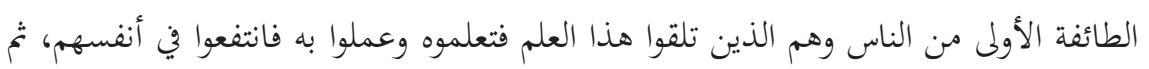

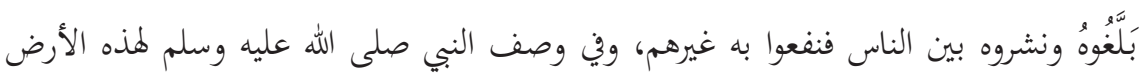

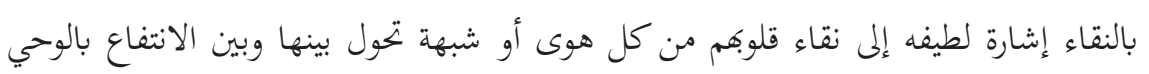

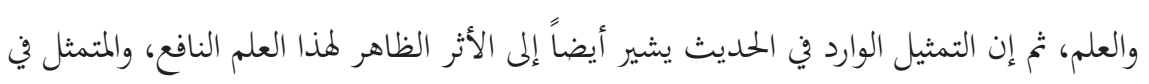


الأعمال الصالحة التي تقتصر على العبد نفسه، والأعمال التي يتعدى نفعها وأثرها إلى الآخرين،

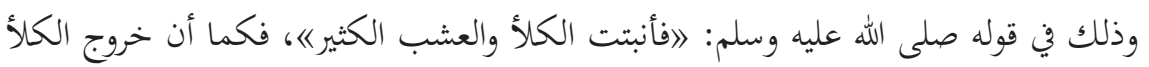
والعشب من هذه الأرض الطيبة بعدما أمطرت هو نتيجة طبيعية، فكذلك صدور الأعمال

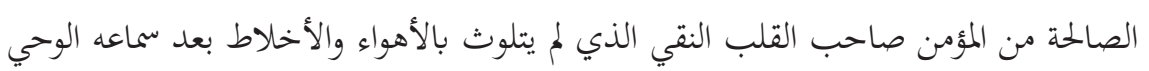

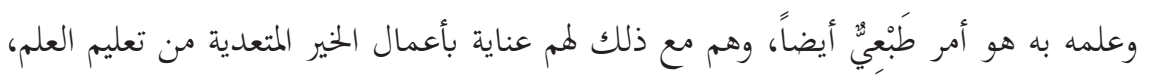

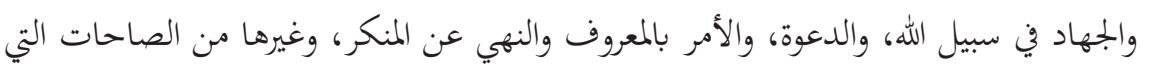
يتعدى نفعها للناس قاطبة. النوع الثاني: هي الأرض الصلبة الجافة التي يستقر فيها الماء لكنها لا تشربه ولا تنبت الزرع،

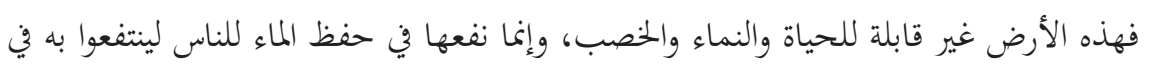

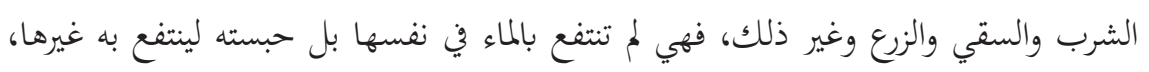

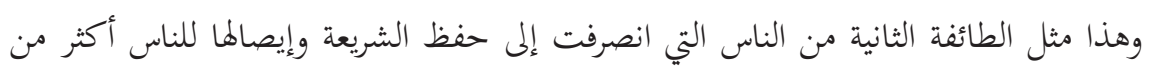
انصرافها إلى العمل، فمن الناس من يحمل المعرفة بالوحي والشرع وليس لديه من الإيمان واليقين

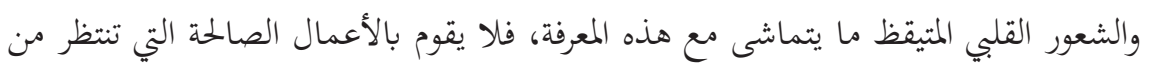

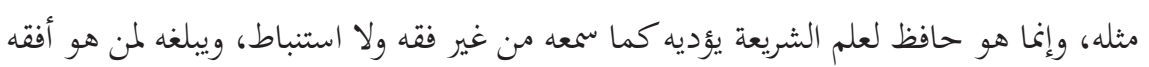

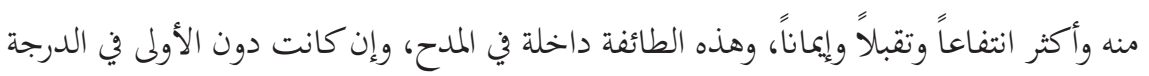

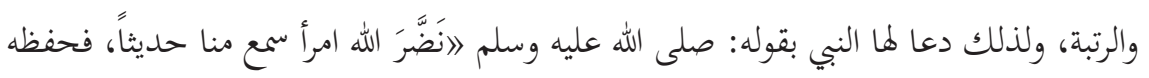
حتى يبلغه غيره، فإنه رب حامل فقه ليس بفقيه، ورب حامل فقه إلى من هو أفقه منه||(Y). النوع الثالث: هي الأرض المستوية الملساء التي لا تشرب الماء، ولا تمسكه فينتفع به غيرها، ولا تصلح كذلك للإنبات والزرع، وهذا مثل الطائفة الثالثة المذمومة التي لم تحمل الوحي والعلم

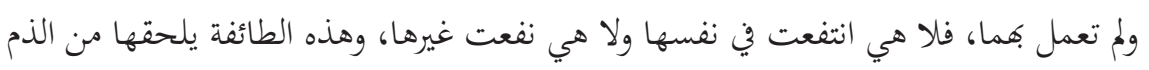

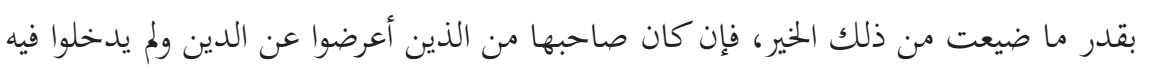

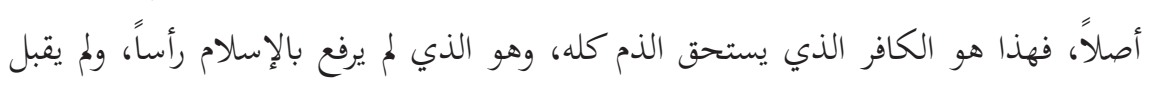
هدى الله الذي أرسل به النبي صلى الله عليه وسلم، وإن كان له نصيب من الإسلام، لكنه لم 
يتعلم العلم، ولم يعمل به، ولم يبلغه لغيره، ولذلك يلحقه من الذم بقدر ما فرط في جنب الله

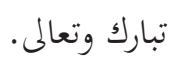

\section{ثالثاً: نتائج البحث وتوصياته}

خلص البحث إلى جملة من النتائج والتوصيات، ومن أهها:

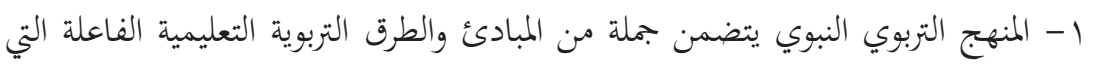

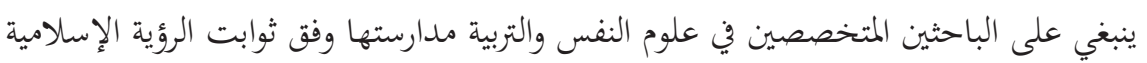

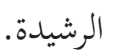

r القد تنوعت طرق وأساليب منهج النبوة الخاتمة وتباينت في التربية والتعليم، ويظهر ذلك

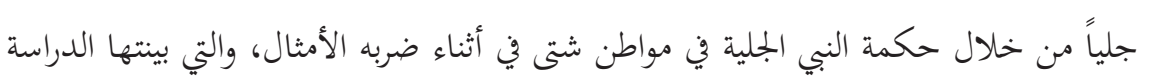
أصولاً.

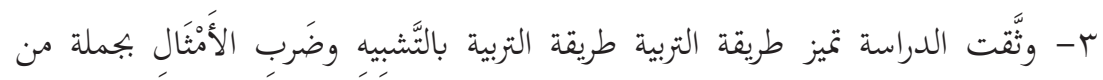

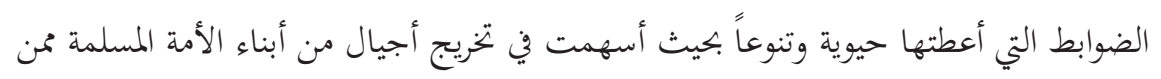
تحلو بأعلى درجات الخُلقُ الكريم والعمل المتقن. ع - توصي الدراسة بأهمية إنجاز دراسات تحليلية تأصيلية نقدية تفنّّد دعاوى جائرة مفادها

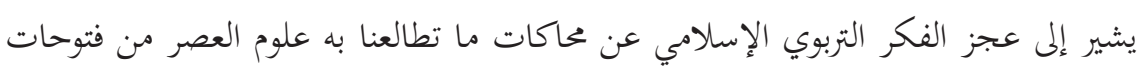

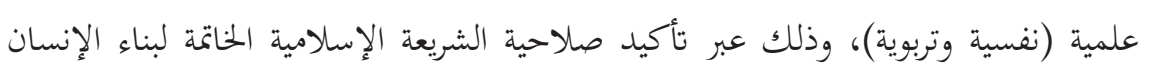
الصالح الناجح في كل عصر ومكان.

\section{رابعاً: مصادر البحث ومراجعه}

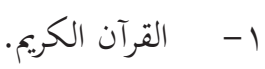

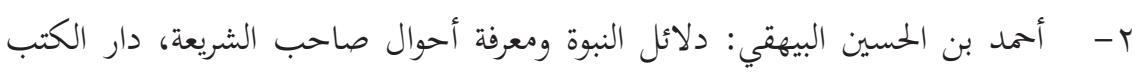

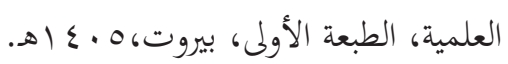

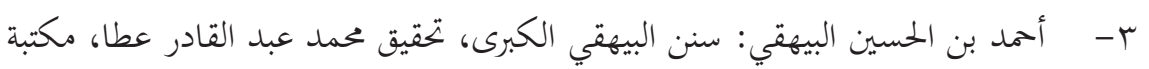

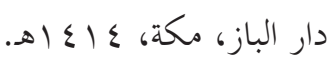


ع - أحمد بن علي بن حجر العسقلاني: تلخيص الحبير في تخريج أحاديث الرافعي الكبير،

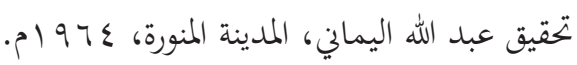
ه - الحاكم محمد بن عبد الله النيسابوري: المستدرك على الصحيحين، تحقيق مصطفى عبد القادر عطا، دار الكتب العلمية، الطبعة الأولى، بيروت، . 999 ام. م.

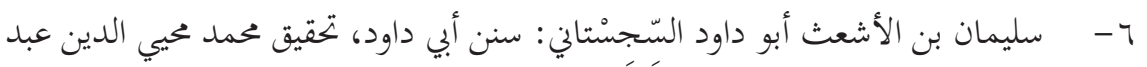

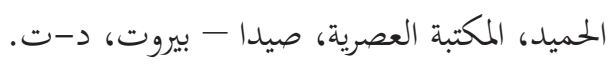

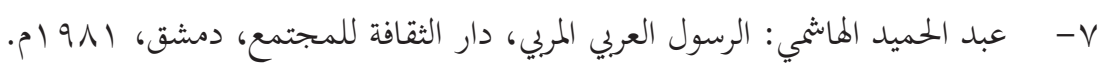

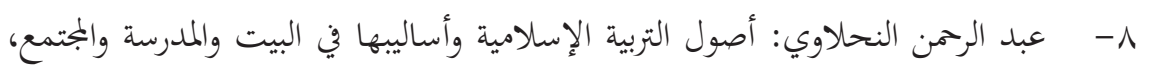

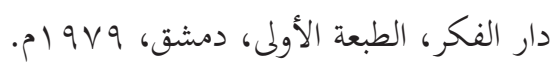

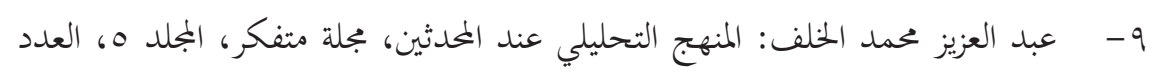
.9 - - ا عبد العزيز محمد الخلف :مناهج البحث عن أحوال الرواة عند المحدثين - دراسة تأصيلية

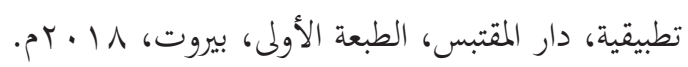

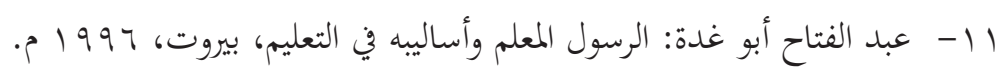

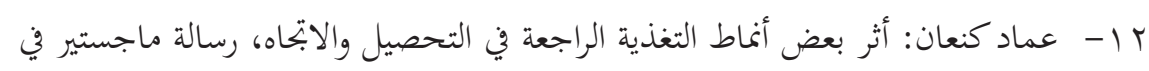
التربية، جامعة دمشق، كلية التربية، دمشق،V V . . Y م.

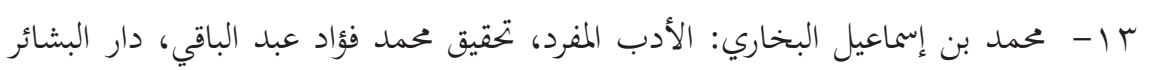

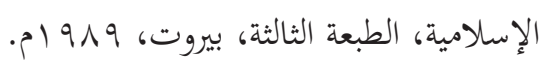
§ ا - مُحََّّد بن إسماعيل البخاري: صحيح البخاري، تحقيق مصطفى البغا، دار العلوم

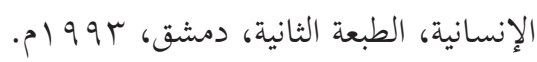
1 - محمد عثمان نجاتي: الحديث النبوي وعلم النفس، دار الشروق، الطبعة السابعة، القاهرة، . -7 17 مسلم بن الحجاج النيسابوري :صحيح مسلم، تحقيق محمد فؤاد عبد الباقي، دار الدعوة، دار سحنون، الطبعة الثانية، القاهرة، 999 1 م. 


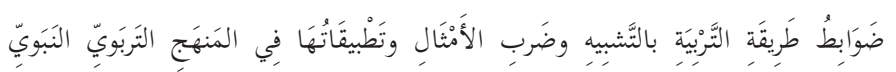

\section{KAYNAKÇA}

Beyhaki, Ebû Bekr Ahmed b. el-Hüseyin b. Ali. Delailün-nübüvve ve ma’rifetu ahvâli sahibişsşeria. Thk. Abdülmu'ti Kal'aci. Beyrut: Dârü’l-Kütübi'lİlmiyye, 1405/1985.

Beyhaki, Ebû Bekr Ahmed b. el-Hüseyin b. Ali. es-Sünenü’l-kübra. Thk. Muhammed Abdulkadir Atâ. Mekke: Mektebetü Dâru’l-Bâz, 1414/1993.

Buhârî, Ebû Abdillâh Muhammed b. İsmâîl b. İbrâhîm Cu’fî. el-Edebü'l-müfred. 3. Baskı. Thk. Muhammed Fuad Abdulbaki. Beyrut: Dârü’l-Beşâiri'l-İslamiyye 1989.

Buhârî, Ebû Abdillâh Muhammed b. İsmâîl b. İbrâhîm Cu’fî. Sahihü’l-Buhari : elCamiu'l-müsnedü's-sahih.3. Baskı. Dımaşk: Dârü'l-İnsaniyye, 1993.

Ebû Davud, Süleyman b. Eş’as b. İshak el-Ezdi es-Sicistani. Kitâbü’s-Sünen = Sünenu Ebû Davud. Thk. Muhyiddin Abdulhamid. Beyrut: el-Mektebetü’lAsriyye, ts.

Ebû Gudde, Abdülfettah. er-Resulü'l-muallim ve esalibihi fi't-ta'lim. Beyrut: y.y. 1996.

Hakim, Ebû Abdullah İbnü'l-Beyyi' Muhammed Nisaburi. el-Müstedrek ale’sSahihayn. dirase ve tahkik. Mustafa Abdülkadir Ata. Beyrut: Dârü'lKütübi’l-İlmiyye, 1990/1411.

Halef, Abdulaziz Muhammed. el-Menhecu't-tahlilî inde'l-muhaddisin. Mecelle Mütefekkir. 5/9.

Halef, Abdulaziz Muhammed. Menâhicu'l-bahs an ahvâli'r-ruvât inde'l-muhaddisin - dirase ta'siliyye tatbikiyye-. Beyrut: Dârü’l-Muktebes 2018.

Hâşimî, Abdulhamid. er-Resulu'l-Arabiyyi'l-murabbi. Dımaşk: Daru's-Sekafe li'lmüctema' 1981 .

İbn Hacer, Ebü’l-Fazl Şehabeddin Ahmed el-Askalani. Telhisü’l- habir fi tahric-i ehadisi'r-Rafiiyyi'l-kebir. Thk. Abdullah el-Yemânî, Medine-i Münevvere: y.y., 1964.

Kenaan, İmad. Eseru ba'di enmâti't-tagziyeti'r-râciati fi't-tahsili ve'l-itticâh. Dımaşk: Dımaşk Üniversitesi Eğitim Fakültesi Yüksek Lisans Tezi 2007.

Kur'an-1 Kerim.

Müslim b. el-Haccac, Ebü'l-Hüseyin el-Kuşeyri en-Nisaburi. Sahih-i Müslim. thk. Muhammed Fuâd Abdülbâkî. Kahire : Dâru Sahnun- Darü’d-Da'vâ 1992.

Nahlavi, Abdurrahman. Usulü't-terbiyeti'l-İslâmiyye ve esalibuha fi'l-beyt. 1. baskı. Dımaşk: Dârü'l-Fikr, 1979.

Necati, Muhammed Osman. el-Hadisün-nebevi ve ilmün-nefs. 7. Baskı. Kahire: Dârü’ş-Şürûk, 2000. 
K7AÜiFD | 2019/2 | CILT: 6 | SAYI: 11

Tirmizi,Ebû İsa Muhammed b. İsa b. Sevre es-Sülemi. el-Câmiü’s-sahih = Sünenü'tTirmizi. tahkik ve şerh Ahmed Muhammed Şakir, vd. 2. Baskı. Kahire: Mustafa el-Babi el-Halebi, 1975. 